\title{
Prospects of Weather Index-Based Crop Insurance in Bangladesh
}

\author{
Md. Tareq Hasan \\ Department of Business Administration, Sheikh Fazilatunnesa Mujib University, Jamalpur, Bangladesh
}

\section{Email address:}

tareq_sfmu@outlook.com

\section{To cite this article:}

Md. Tareq Hasan. Prospects of Weather Index-Based Crop Insurance in Bangladesh. International Journal of Agricultural Economics. Vol. 4, No. 1, 2019, pp. 32-40. doi: 10.11648/j.ijae.20190401.15

Received: January 9, 2019; Accepted: February 11, 2019; Published: February 27, 2019

\begin{abstract}
Agricultural sectors of Bangladesh are frequently affected by natural disasters such as droughts, excessive rainfall, floods, flashflood, heavy fog, earthquakes, storm, cyclones, salinity and landslides. Agriculture or crop insurance is an important method by which farmers can stabilize their income and investment against disastrous effect of losses for natural hazards or low market price of the crops. Crop insurance helps the farmers of developing and under developed countries to initiate production activities after a bad agricultural period. At first, Green Delta Insurance Company has started Weather Index Insurance since 2015 by supporting of World Bank group in Bangladesh. Later on, Sadharan Bima Corporation (SBC) also proposed another new project named 'Weather Index-Based Crop Insurance (WIBCI)'. Agriculture or crop insurance should be based on risk management strategy. The purpose of this study is to implement and further possibility of weather index-based crop insurance in Bangladesh and descriptive method is used to represent the information. The possible result of this study is continuous crops production activities of the farmers after a natural disaster. Bangladesh should have started agriculture or crop insurance system earlier for better output from agricultural sectors.
\end{abstract}

Keywords: Agriculture, Crop, Disaster, Insurance, GDIC, WIBC

\section{Introduction}

Agriculture is the largest employment sector in Bangladesh and most of the people earn their living from this sector. Approximately 2,86,95,763 families are involved with agriculture and total cultivable land is $85,60,964.75$ hectares where irrigation or rice is being produced about in $74,06,822.87$ hectares. Bangladesh is the fourth largest rice producing country in the world. According to information of Ministry of Agriculture, total 34.7101 million metric ton rice was produced in FY 2016-2017 where wheat production was only 1.348 million metric ton and maize was 2.759 million metric ton. Jute, potato and mango are also primary crops here and more than 120 crops like vegetable and others are being grown in the country. Average approximate cultivation of some different crops in Bangladesh is shown through a pie chart;

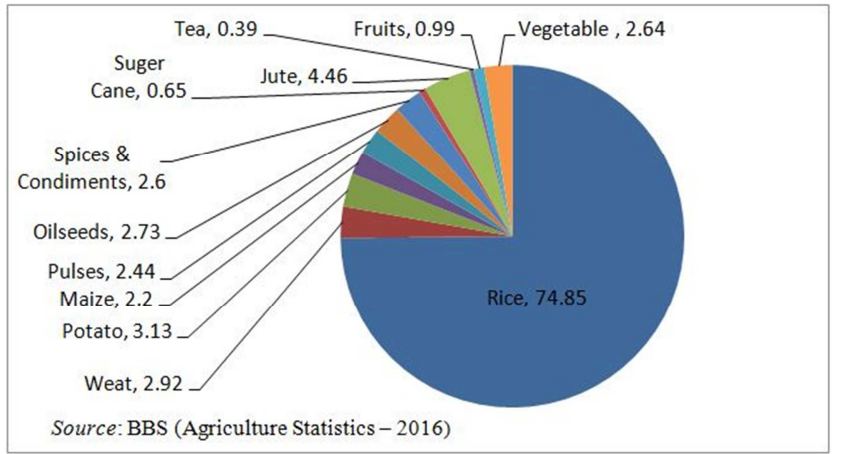

Figure 1. Cultivation Percentage of Different Crops in Bangladesh.

There are three kinds of land which treated as single, double and triple cropped area in Bangladesh and cropping intensity of land is $192 \%$. Including all kinds of cultivation Bangladesh has got total 1,52,45,841.93 hectares as cropped area and contribution of agriculture sector to Gross Domestic Product (GDP) is $14.75 \%$ which remarkable.

In developing countries the agriculture sector absorbs 
about $22 \%$ of the total damage and losses caused by natural hazard. Due to geographic position of Bangladesh every year it often faces excessive rainfall or flood or flashflood, landslide, heavy fog, storm or cyclone massively in different areas. So, crops are damaged more or less in every food year due to these natural disasters. A table is given below for showing crops damage of last nine years;

Table 1. Crops Damaged by Natural Deserters (Period 2008-2016).

\begin{tabular}{lll}
\hline Food Year & Name of Crops & Total Loss in Metric Ton \\
\hline \multirow{2}{*}{$2008-09$} & Rice & $1,14,455$ \\
& Summer Vegetable & 670 \\
$2009-10$ & Potato & 54,249 \\
$2010-11$ & Rice & $3,69,591$ \\
& Rice & 12,580 \\
$2011-12$ & Rice & 77,534 \\
& Red-Amaranth & 5,264 \\
$2013-14$ & Kharif Chiles & 2,542 \\
& Rice & 5,502 \\
& Rice & $1,25,250$ \\
$2014-15$ & Red-Amaranth & 04 \\
& Tomato & 37 \\
& Cabbage & 11 \\
$2015-16$ & Cauliflower & 22 \\
\hline
\end{tabular}

Source: BBS (Agriculture Statistics - 2016).

Beside these, the fisheries, dairies and poultries which subsector of agriculture are also mostly affected by excessive rainfalls, flashfloods, floods, cyclones, storms and tsunamis. Another table is shown below mentioning damage and loss percentage from FY 2009 to 2015 by disaster categories.

Table 2. Damage and Loss by Disaster Categories (Period 2009 - 2015).

\begin{tabular}{lllll}
\hline \multirow{2}{*}{ Disaster } & \multicolumn{2}{l}{ Damage and Loss Percentage (2009-2015) } & Land & \\
\cline { 2 - 5 } & Crops & Poultry & Fishery & 0.38 \\
\hline Drought & 4.96 & 0.04 & 0.10 & 4.87 \\
Flood/Flashflood & 12.03 & 0.32 & 1.08 & 0.84 \\
Water Logged & 4.70 & 0.11 & 1.34 & 0.00 \\
Cyclone & 2.28 & 0.41 & 1.14 & 0.00 \\
Tornado & 0.53 & 0.02 & 0.00 & 1.80 \\
Storm/Tidal Surge & 1.27 & 0.17 & 1.78 & 0.00 \\
Thunderstorm & 1.35 & 0.06 & 0.00 & 17.23 \\
River/Coasteral Erosion & 0.58 & 0.02 & 0.18 & 0.11 \\
Landslide & 0.00 & 0.00 & 0.00 & 1.50 \\
Salinity & 1.17 & 0.01 & 0.00 & 0.00 \\
Hailstorm & 5.25 & 0.01 & 0.00 & \\
\hline
\end{tabular}

Source: BBS (Bangladesh Disaster Related Statistics 2015).

Disasters are not only jeopardizing agricultural production and development but also often have cascading negative affects across national economics of a country.

Crops insurance helps the farmers both of developed and developing countries to stable their continuous production of agricultural sectors. Crop insurance is purchased by agricultural producers, including farmers, ranchers and others to protect themselves against the loss of their crops due to natural disasters or low market prices of agricultural commodities. But, Weather Index-Based Crop Insurance is an attractive approach to managing weather and climate risk because it uses a weather index, such as excessive rainfall, flood or flashflood, heavy fog, cyclone or storm etc. to determine payouts and these can be made more quickly and with less argument than typical for conventional crop insurance.

Agricultural insurance products can be classified into three main groups based on the method of determining how claims are calculated. These classifications are summarized in below using a table.

Table 3. Classification of Agricultural Insurance Products.

\begin{tabular}{lc}
\hline Type of Agricultural Insurance Product & Payouts \\
\hline a) Indemnity Based Agricultural Insurance (insurance payouts based on the actual loss at the insured until level) \\
1. Named Peril & Percentage of Damage \\
2. Multi Peril & Yield Loss \\
\hline
\end{tabular}




\begin{tabular}{ll}
\hline Type of Agricultural Insurance Product & Payouts \\
\hline b) Index based Agricultural Insurance (insurance payouts based on an index measurement) & Area-yield Loss \\
3. Area-Yield Index & Weather Index payout scale \\
4. Crop Weather Index Insurance & NDVI Index payout scale \\
5. NDVI Index Insurance & Livestock mortality index payout scale \\
6. Livestock Mortality Index Insurance & Ignition focus/ burnt area payout scale \\
7. Forestry Fire Index Insurance & Yield and Price Loss \\
c) Crop Revenue Insurance (insurance payouts based on yield measurement and crop prices) & \\
8. Crop Revenue Insurance & \\
\hline
\end{tabular}

Source: World Bank, 2009.

With WIBCI contracts, an insurance company doesn't need to visit the policyholder to assess damages and arbitrate claims. Instead, if the weather recorded by gauges is cross a standard level and considered as disaster, then the insurance pays out automatically. Faster payouts mean that farmers don't need to take any kinds of loan or sell their assets to survive and rearrange themselves. So, WIBCI is being implementing over all developing or under developing countries and it attractive to low-income farmers. In Bangladesh, Green Delta Insurance Company has started Weather Index Insurance since 2015 by supported of World Bank and according to information of Sadharan Bima Corporation which is the only state owned organization, is also going to introduce "Weather Index-Based Crop Insurance" recently as a pilot project under the Ministry of Finance. The details of both projects have been illustrated in 'Findings of the Study' part in this research paper.

\section{Literature Review}

Literature review on the area of crop insurance and weather index-based crop insurance are illustrated shortly in this part.

Iturrioz (2009) states that from a geographical perspective, the bulk of the agricultural insurance in the United States and Canada, with approximately $62 \%$ of the market. This is followed by Asia with $18 \%$ and Europe with $16 \%$. The balance comprises $2 \%$ in Latin America and 1\% in Oceania and Africa respectively.

Nagaraju (2013) discussed in his journal that weather index-based insurance was formally introduced to Indian farmers in 2003 through a programme initially supported by World Bank. Weather Based Crop Insurance / Rainfall Insurance during the year 2003-04 the private sector came out with some insurance products in agriculture based on weather parameters, he also added.

CCAFS (2013) mentioned that a number of African countries, including Ethiopia, Kenya, Malawi and Mozambique, have also experimented with weather indexbased insurance schemes. The schemes protect farmers from catastrophic losses due to weather calamities, such as droughts, floods and extreme temperatures. Partly because the private sector is less well developed in this region, uptake has so far been mainly on a pilot scale. Climate Change, Agriculture and Food Security(CCAFS) is watching these initiatives - including the ILRI-led index-based livestock insurance project - carefully in order to test and apply such mechanisms in CCAFS countries in Africa in future.

It has been founded that multiple risk crop insurance problem differs from many other forms of insurance, including those which have been the subject of most theoretical attention, in that a production process in insured. Insured losses depend on the interaction of a wide range of exogenous variables such as rainfall and temperature and endogenous variables including decisions on the level and timing of input use, Quiggin, J., Karagiannis, G. and Stanton J. (n.d.).

Swain (2014) tried to reveal that to reduce administrative cost of collecting data on yield and to make faster claim payment in a transparent manner; during 2007 the Central Government of India launched Weather Based Crop Insurance Scheme (WBCIS) on pilot basis. Following the guidelines of the Central Government, since 2008 Odisha has been implementing WBCIS in few drought prone blocks in western Odisha on pilot basis. Initially during 2008, WBCIS was available only to non-loanee farmers.

Dick and Wang (2010) narrated in their conference paper that there is interest in index insurance, including amongst governments, donors and academics. Index insurance, either as parametric weather based index or area yield index insurance, is seen as overcoming some of the constraints inherent in traditional insurance and particularly multiple peril (yield-based) crop insurance (MPCI).

Lomot, Lyskawa and Rozumek (2015) stated in their conference paper that Poland is the third country in EU in terms of agricultural area and has started crop and animal insurance since 2006 (since 2008 obligatory crop insurance). The subsidized crop insurance in limited and their scope is relatively narrow, only $29 \%$ of surveyed farmers financed any damage through insurance whereas financing of insurable events in $75-87 \%$ currently comes from farmers' private resources.

Marza, Angelescu and Tindeche (2015) illustrated in their paper that the insurances do not represent a panacea for solving the problem of global food security, but may represent an important measure for meeting the objectives related to this problem. The global insurance industry is constantly adapting to the existent problems and may represent an important partner that provides the necessary coverage against different risks threatening the agricultural production and thus contributing to the diminishing of global food insecurity.

IFC (2018) stated that small farmer in Zambia are vulnerable to weather-related shocks such as drought, 
flooding and irregular rainfall. Insurance can be a good risk management tool for these farmers, but the traditional insurance market largely fails to meet their demand for affordable insurance. The Zambian government has recently awarded Mayfair a contract to offer weather-based index insurance to farmers who benefit from government input subsidies. The additional funding provided through the International Finance Corporation (IFC) grant will enable Mayfair to successfully carry out the government contract and reach a total 400,000 farmers in Zambia, including those reached through the grant extension.

Several studies has been included here regarding agricultural insurance, but no exclusive studies found on this area in Bangladesh since the issue is fully new and proposed. So researcher attempts to focus on prospect of weather indexbased crop insurance in Bangladesh.

\section{Objectives of the Study}

1. To study the initiatives taken to implement weather index-based crop insurance in Bangladesh.

2. To find out the possibility of index-based crop insurance in Bangladesh.

\section{Methodology of the Study}

A stable agriculture is most vital issue for the food security of a country. Insurance in agriculture is fully new concept here in Bangladesh. As an agriculture dependent country, Bangladesh has got great significance of crop insurance or weather index-based crop insurance for continuous agriproduction after a bad agricultural period. This study is based on secondary data. All the secondary data has been collected from internet, newspapers, articles, books and magazines. In this study data are analyzed in descriptive method.

\section{Findings of the Study}

Researcher finds in this study that weather index-based crop insurance is prospecting issue for developing and continuing agricultural production of Bangladesh. Supported by GIIF and IFC, Bangladesh has started weather index insurance in 2017 for more than 25 products like Rice, Hybrid Rice, Potato, Maize, Tomato, Okra etc. But this is limited selective products for insurance in agriculture dependent country like Bangladesh and only one company is offering crop insurance among more than 40 companies.
Ministry of Finance is also going to introduce weather indexbased crop insurance over the country which should have started earlier. Details findings of the study have been given below briefly.

\subsection{Project of Green Delta Insurance Company}

Supported by the Global Index Insurance Facility (GIIF), the International Finance Corporation (IFC) is working with its partner Green Delta Insurance Company (GDIC), to develop insurance products to address perils such as drought, excess rain, heat waves and cold spells in Bangladesh. This project has been providing technical support to Green Delta for weather data analytics, risk rating, pricing and product design and has been engaging with distribution channels in the country since 20015 .

Clients: Cassava farmers via PRAN Food Ltd. tomato farmers in lowlands (Through an NGO) and farmers producing Hybrid Rice seeds (Supreme Seeds Company).

Partners: Green Delta Insurance Ltd is insurer here and Distribution Channel: Agribusinesses (Input Suppliers, Contract Farming Entities), NGO-MFIs and banks.

Products: More than 25 Weather Index Insurance products are designed for a large variety of crops (Rice, Hybrid Rice, Potato, Maize, Tomato, Okra, Cassava etc.) for different districts of Bangladesh across the three cropping seasons. Three of these products were piloted as of February 2017. A Group of Yield Index Insurance product is also designed (and piloted) for Hybrid Rice.

Insured Crops: Rice, Potato, Maize, Cassava, Tomato, Okra etc. Insured Perils: Drought (dry Spell), excess rain (wet-spell), heat waves (hot spell) and cold spell.

Results and Impacts: As of February 2017, Green Delta Insurance Company has launched agri-insurance pilots with multiple distribution partners including PRAN Food Ltd. (for Cassava). Supreme Seeds Limited(Hybrid Rice) and Renaissance (an NGO-MFI) (Tomato). In the pilot with tomato farmers, the process has motivated all 200 covered farmers (of this pilot) to buy insurance for other crops in other seasons. In December 2017, Green Delta Settled a claim of 1,000 tomato farmers in Begarhaat, who have been insured by Weather Index-Based Agri Insurance. The project has also been providing capacity-building activities for GDIC to use in product pricing and administration. By the end of the project, the project expects to have covered approximately 75,000 farmers in the country.

A short snapshot of project has been given below;

Table 4. Project Details of Green Delta Insurance Ltd.

\begin{tabular}{ll}
\hline PROJECT SNAPSHOT & \\
\hline Market Launch & $2015-2016$ \\
Clients & Cassava farmers via PRAN Foods Ltd. Tomato farmers via Renaissance \\
Partners & Insurer: Green Delta Insurance Ltd. \\
& Distribution Channels: MFIs and Agribusinesses (Contract Farming) \\
Products & Weather Index Insurance for cassava and tomato farmers Yield Index \\
Insured Assets & Insurance for Rice has also been developed \\
Insured Perils & Cassava, Tomato \\
\hline
\end{tabular}


Next Steps of Project: The project aims to create an ecosystem where agriculture insurance will be delivered through multiple partners in the agriculture value chain of Bangladesh. GDIC will work towards multiple pilots in 2017 and 2018 to deliver agriculture insurance as a bundled product with banks, MFIs, seed companies, input suppliers and contract farming entities. These pilots are expected to create a demonstration effect in Bangladesh as well as to global observers, highlighting the value of agriculture insurance in the value chain. The project plans to leverage the existing network of GDIC to link up with several distribution channels, targeting a variety of farmers for scale and volume to reaching commercial sustainability.

\subsection{Proposed Project of Sadharan Bima Corporation}

Supported by Ministry of Finance, Sadharan Bima Corporation is going to introduce a new proposed project "Weather Index-Based Crop Insurance" in Bangladesh recently. The project details are given below;

Project Description: The proposed grant aims to develop and implement weather index-based crop insurance in Bangladesh as an adaption tool to reduce the climate variability and extreme weather vulnerability of Agriculture sector, especially impacting small farm households. Climate induced disasters and other extreme weather events mostly affecting the country's agricultural production such as flood, drought, cyclone, storm surge and salinity intrusion are directly related to climate change which are threatened to have more intense and frequent occurrence.

Objectives of the Project: The long-term goal of the project is to increase the resilience of farm households to climate and natural disaster risks. It is expected that through WIBCI, farm income losses caused by climate and natural disaster risk will be reduced. The specific objectives of the project are; (i) accomplishing pilot testing of viable WISCI products, (ii) improving and strengthening policy and regulatory framework and (iii) capacity development, awareness raising and weather infrastructure upgrading.

Activities of the project (Component wise): In light with the above goal and objective, the project encompasses four components such as Component A: Pilot testing of viable WIBCI products, Component B: Formulating and strengthening policy and regulatory framework, Component $\mathrm{C}$ : Capacity building, awareness raising and upgrading of selected weather infrastructure and Component D Project management, monitoring and audit. Activities of the components are as follows;

Component - A

I. Selection of at least three pilot areas and crops on the basis of exposure to various weather risks

II. Design and pilot testing of a set of farmer-friendly WIBCI contracts for at least three districts

III. Regulatory approval of WIBCI products filed by at least one public and private insurer. This should entail detailed agreement on premium rates, underwriting norms, reinsurance and claims settlement parameters, distribution costs, etc.

Component - B

I. Development of regulatory framework/ guidelines for WIBCI

II. Approval by the Bangladesh Meteorological Department (BMD) of data accreditation standards consisting of approved weather station infrastructure and user guidelines, including transparent data-collection and datasharing methods and utilization of satellite data. Validation by Insurance Development Regulatory Authority (IDRA) of specific customer protection regulation for WIBCI contracts.

Component - C

I. Capacity development of weather data agencies and agriculture research institutions for at least 100 staff members.

II. At least 20 weather stations upgraded to provide reliable data

III. Insurance literacy and climate risk awareness among at least 6,000 farmers

IV. WIBCI sales, administration and operational skills training for at least 300 staff members from insurance companies and distribution partners

V. Operational module on how to design and pilot WIBCI, particularly related to underwriting distribution and claim management for use by insurers, regulators and other intermediaries

Component - D

I. Detailed work plan and implementation guidelines

II. Management Information System (MIS) for the project

III. Impact evaluation framework for the project

IV. Accounting and financial management system related to project implementation, in accordance with $\mathrm{ADB}$ requirements

V. Financial audit report for the project

\subsection{The Growth of Agricultural Insurance}

Livestock and crop hail insurance was sold before 1800 , the growth in agricultural insurance truly began in the first half of the $20^{\text {th }}$ century with the establishment of government-sponsored insurance programs. In the United States, Canada and Japan, such programs date to the late 1930s. Initially those programs were operated on a pilot basis with limited crop and regional coverage. By the time the Uruguay Round was launched in 1986, total agricultural insurance premiums for these three countries totaled about US\$ 1.6 billion. A number of other countries' insurance programs date to the second half of the $20^{\text {th }}$ century; these were small, with total premium volume likely less than $\$ 1.0$ billion in 1986 .

The rapid growth in agricultural insurance markets since 2004 is attributable to several factors, including the appreciation in commodity prices; increased government subsidies, resulting in higher coverage levels in the US market and growth of agricultural insurance in emerging economies, particularly China. There was remarkable growth of US and China crop insurance markets since 2001. In that 
year, the average coverage level in the United States was $63 \%$, with $48 \%$ of enrolled area insured at $70 \%$ coverage or higher. By 2013, because of increased subsidies, the average coverage level was $72 \%$, with $78 \%$ of area insures at coverage level of $70 \%$ or higher. Hurricanes Harvey, Irma and Maria as well as a number of severe wildfires and other disasters were throughout the year and more than $\$ 3.4$ billion in indemnities had been paid thus for 2017. China's agricultural premiums remained at relatively low levels in 2007, when premium subsidies were introduced, which resulted in premium volumes increasing from $\$ 300$ million in 2007 to almost \$5 billion in 2013.

In developed economies such as the United States, Japan, Canada and Europe, agricultural insurance is generally characterized by indemnity-based programs that provide crop and livestock coverage against named perils, multiple perils and more recently, price and revenue risks. Individual-based coverage is expensive because of the high cost of administering contracts and adjusting losses. Those countries accounted for more than $90 \%$ of total premiums at an average subsidy rate of $47 \%$.

\subsection{Agricultural Insurance and WTO}

World Trade Organization (WTO) is playing a vital role for agricultural development and also emphasizing on agricultural insurances with WFP and IFPRI internationally. WTO has kept some paragraphs for these issues in its Articles of Association (AoA). Under the AoA, members are required to make annual notification to the WTO on the extent of their domestic support measures.

Many WTO members have notified support under paragraph 8 for disaster assistance; the main issue surrounding these notifications is a lack of transparency. Few of the programs notified appear to be agricultural insurancetype programs; rather, they are programs responding to ad hoc disasters. Based on the numerous questions and answers exchanged during review process of the WTO Committee on Agriculture's regular meetings, however, it is not clear that many countries actually meet all the criteria.

But the members of the WTO should consider deeply about all kinds of natural disasters that affect the agricultural sectors. So that, WTO can take initiatives against the affects of the disasters and also can analyze all kinds of issues provided by the member countries for better support and best agricultural future.

\subsection{History of Index Based Insurance}

Index insurance schemes have been piloted in a number of developing countries, with somewhat limited success. As early as 1999, weather index-based insurance was being discussed in academic papers as an alternative solution for developing agricultural economies. In 2002, donors began to finance the piloting of these ideas. In particular, the World Bank's Commodity Risk Management Group (CRMG) was allocated trust funds from the Swiss and the Dutch governments to pilot weather insurance for farmers to complement its price risk management work in commodity markets.

CRMG has been involved in many weather risk management technical assistance projects to commercial entities in the developing world. In 2003, Hyderabad-based micro finance institution BASIX (a sister concern of Bhartiya Samruddhi Investments and Consulting Services Ltd. (BASICS Ltd.) and Mumbai-based insurance company Industrial Credit and Investment Corporation of India (ICICI) Lombard, with technical assistance from CRMG launched first pilot program for index-based weather insurance in the developing world in the Mahahbubnagar district of Andhra Pradesh. This pilot program sold weather insurance policies protecting against low rainfall to 200 groundnut and castor farmers. In 2004, BASIX incorporated farmer feedback into the design of the second generation of improved weather insurance products that were sold to over 700 farmers, several of whom were repeat customers from the 2003 pilot. In 2005, BASIX scaled up the program further, selling over 7,600 policies in 36 locations in six Indian states. These new policies were refined versions of the 2004 products and offered improved risk management features for farmers, but had a generic standardized structure which made it easier for BASIX to retail to many clients in many locations. Intense training sessions with loan officers, who became literally one-stop-shop customer service agents, allowed BASIX to offer large array f rainfall insurance products to its farmer clients. In 2006, BASIX sold rainfall and multi-peril weather contracts including temperature and relative humidity to over 11,000 customers. During that time, the Indian weather insurance market has grown rapidly and four insurance companies have sold weather insurance policies to farmers.

Since 2003 there have been several other pilots around the world, including completed pilots in Ukraine, Ethiopia and Malawi and upcoming pilots in Kenya, Tanzania, Thailand and Central America. Successes like the market growth in India have had significant demonstration effects and have proven that weather risk management for farmers in the developing world is possible through insurance-type instruments.

From these experiences, the group has begun to synthesize some best practices on how to create successful weather insurance schemes for farmers and how to make such initiatives sustainable and scalable, particularly in Africa.

\subsection{Index Based Insurance in Some Regions}

The Mexican Agricultural Fund for Natural Disasters (CADENA) aims to internationally reinsure part of the costs of its state managed relief programs. CADENA was launched in 2003 by the Ministry of Agriculture and contains two main components: a) the Catastrophe Agricultural Insurance (SAC) program for farmers, livestock producers, aquaculture farmers and fishermen; and b) in States where SAC is not provide, direct compensation payments to farmers in the event of natural disasters. Under the program, State Governments purchase insurance to protect their budgetary allocations against natural disaster compensation for the most 
vulnerable farmers.

The Caribbean Catastrophe Risk Insurance Facility (CCRIF) insures Caribbean countries against the cost of relief during natural disasters like; earthquakes, tropical cyclones and excess rainfall. The first multiple country risk pooling program of its kind, CCRIF was developed to help mitigate the short-term cash flow problems small developing economies suffer after major natural disasters. CCRIF represents a cost-effective way to pre-finance short-term liquidity to begin recovery efforts for an individual government after a catastrophic event, thereby filling the gap between immediate response aid and long-term redevelopment.

The African Risk Capacity (ARC) provides insurance cover against extreme weather events to participating African countries. By combining early warning and contingency planning with an insurance mechanism, member states have access to funding shortly after an extreme weather event occurs while the pre-planning activities ensure that payouts are used effectively, ARC's insurance pool was launched with four countries (Kenya, Mauritania, Niger and Senegal) in 2014.) Already in the first insurance season ARC proved its effectiveness. After a drought hit the Kenya, Mauritania, Niger and Senegal received payouts of 26 million US dollar which benefitted around 1.3 million people and 500,000 livestock. In 2015 ARC's risk pool was expanded to the Gambia, Malawi and Mali providing more than 180 million USD in drought coverage for the seven countries.

The Pacific Risk Insurance Pilot is another multiple country program that enables Pacific Island Countries (PICs) to secure aggregate insurance coverage worth US\$ 43 million against tropical cyclones and earthquakes/tsunamis. This support is crucial given the exposure of the region to disasters - extreme natural events have affected more than 9.2 million people in the Pacific since 1950 and caused damage of about USD 3.2 billion. The World Bank acts as an intermediary between PICs and a group of reinsurance companies, which were selected through competitive bidding process.

\subsection{Guideline for Weather Index-Based Insurance of IFAD and WFP}

IFAD and WFP have been working together on weather index-based insurance (WII) since 2008 through the joint Weather Risk Management Facility (WRMF). They have given a technical guide for findings and experience to date into practical decision-making steps for donors and practitioners.

It goes through each phase of the WII project design and management process, including;

a. Assessing if WII is feasible

b. Developing a roadmap for pilot and implementation

c. Scaling up and sustaining WII

The guide includes background information, explanations and resource recommendations to help inform decisionmaking. It shows how WII operates best as part of an integrated approach to risk management, when constraints such as lack of access to finance, improved seed, inputs and markets can be simultaneously addressed.

\subsection{New Partners for Promoting IBI}

The Global Index Insurance Facility (GIIF) of the World Bank or IFC signed knowledge partnership agreement the ILO's Impact Insurance Facility in September 2014. The partnership focuses on raising awareness and developing knowledge about index insurance across the glob and included the launch of the Community of Index Insurance Practitioners ("Index Insurance Forum") in November 2014 during the GIZ-BMZ Conference on Agriculture Insurance in Berlin.

The Global Action Network (GAN) on Agricultural Insurance was formed in November 2014 by the ILO's Impact Insurance Facility with support from the USAID and the BASIS Assets and Market Access Innovation Lab/14 Index Insurance Innovation Initiative at the University of California.

AXA Corporate Solution, Swiss Re Corporate Solutions and Grameen Credit Agricole also demonstrated their commitment to expanding the index insurance market in the developing world by joining GIIF in a knowledge partnership in January 2015 and launching an advocacy coalition in July 2015. The partners will collaborate to disseminate information on various index-insurance programs, share market intelligence through GIIF's grantee and partner network, share best practices on product design and relevant technical data, provide networking and communication support for increased access to industry events and technical forums and actively participate in the Community of Index Insurance Practitioners.

\subsection{Recommendations}

1. Weather index-based crop insurance should be offered for most of allcrops.

2. All the insurance company should offer WIBCI or crop insurance scheme over the country.

3. Proposed "Weather Index-Based Crop Insurance" of SadharanBima Corporation which under government should introduce over the country soon.

4. More produced fruits like mango, lichee, homie, pineapple, watermelon etc could be considered under WIBCI.

5. Weather index-based insurance should be multi-peril coverage.

6. List of farmers for WIBCI should be area wise with mentioning amount of agricultural land.

7. Listed farmers have to maintain a particular bank account for insurance.

8. Insurance companies should research more on WIBCI and other crop insurance policies for consideration of best offer to farmers.

9. Consideration of natural disaster will have to be specific scaling system depend on type of disaster.

10. Coverage percentage on total losses should be 
mentioned clearly during offering policies to farmers.

11. Payment should be transferred to farmers immediately after the disaster as per index.

12. Policy should be clear for group or individual payments.

13. Government and private organizations will have to work together for better result of Weather Index-Based Crop Insurance.

14. Low market price for specific crop could be considered for WIBCI or crop insurance.

\section{Conclusion}

Success rate of index-based insurance is not that much remarkable without India. Nevertheless, several international initiatives have been launched to promote and developed
WIBCI to achieve greater scale. If these efforts are to succeed, there needs to be a better understanding of the constraints on WIBCI, how these might be overcome and at what cost relative to the potential benefits of WIBCI. Since Bangladesh is an agricultural country within South Asia zone and a significant percentage of GDP is depend on these sectors. So, agricultural sectors should be considered under best policies of insurance where most of all farmers will be felt secure to produce and production process will be continued after any kinds of natural disaster. Bangladesh should study or analyze more and more regarding the crop insurance and index-based insurance policies before implementing over the country and should launch the policies immediately by both government and private sectors for better outputs of agricultural sectors.

\section{Acronyms}

\begin{tabular}{|c|c|}
\hline ADB & Asian Development Bank \\
\hline AoA & Articles of Association \\
\hline $\mathrm{ARC}$ & African Risk Capacity \\
\hline BBS & Bangladesh Bureau of Statistics \\
\hline BMD & Bangladesh Meteorological Department \\
\hline CADENA & Mexican Agricultural Fund for Natural Disasters \\
\hline CCAFS & Climate Change, Agriculture and Food Security \\
\hline CCRIF & Caribbean Catastrophe Risk Insurance Facility \\
\hline CRI & Crop Revenue Insurance \\
\hline CRMG & Commodity Risk Management Group \\
\hline GAN & Global Action Network \\
\hline GDIC & Green Delta Insurance Company \\
\hline GDP & Gross Domestic Product \\
\hline GIIF & Global Index Insurance Facility \\
\hline IBI & Index Based Insurance \\
\hline ICICI & Industrial Credit and Investment Corporation of India \\
\hline IDRA & Insurance Development Regulatory Authority \\
\hline IFAD & International Fund for Agricultural Development \\
\hline IFC & International Finance Corporation \\
\hline IFPRI & International Food Policy Research Institute \\
\hline ILO & International Labor Organization \\
\hline MIS & Management Information System \\
\hline MPCI & Multiple Peril Crop Insurance \\
\hline NDVI & Normalized Deviation Vegetation Index \\
\hline NGO & Non-Government Organization \\
\hline PICs & Pacific Island Countries \\
\hline $\mathrm{SAC}$ & Catastrophe Agricultural Insurance \\
\hline SBC & Sadharan Bima Corporation \\
\hline UN & United Nations \\
\hline USAID & United States Agency for International Development \\
\hline USD & United States Dollar \\
\hline WFP & World Food Program \\
\hline WIBCI & Weather Index-Based Crop Insurance \\
\hline WII & Weather Index-based Insurance \\
\hline WRMF & Weather Risk Management Facility \\
\hline
\end{tabular}




\section{References}

[1] Bangladesh Bureau of Statistics. (2017, June 19). Yearbook of Agricultural Statistics of Bangladesh 2016. Retrieved from http://bbs.portal.gov.bd/sites/default/files/files/bbs.portal.gov. bd/page/1b1eb817_9325_4354_a756_3d18412203e2/Yearboo k-2016-Final-19-06-2017.pdf.

[2] Bangladesh Red Crescent Society. (August 16, 2017). Monsoon floods in Bangladesh. Retrieved from https://reliefweb.int/sites/reliefweb.int/files/resources/SitRep_ 2_Bangladesh\%20Flood_16\%20August \%202017.pdf.

[3] Bryla, E. and Syroha, J. (March 2007). Innovation briefs of United Nations (UN). Sustainable Development. Retrieved from http://www.un.org/esa/sustdev/publications/innovationbriefs/no 2.pdf.

[4] CCAFS (2013). Weather index-based insurance. Retrieved from https://cgspace.cgiar.org/bitstream/handle/10568/34366/CCA FS-Index-Insurance.pdf.

[5] Dick, W. J. A. and Wang, W. (2010). Government interventions in agricultural insurance. Elsevier $B . \quad V$. Conference conducted at the meeting of the international conference on agricultural risk and food security 2010 . Retrieved from www.sciencedirect.com.

[6] FAO. (n, d). The impact of disasters on agriculture and food security. Retrieved from http://www.fao.org/3/a-i5128e.pdf.

[7] Hess, U. and Hazell, P. (2016). Innovation and emerging trends in agricultural insurance. Deutsche Gesellschaft fur InternatioaleZusammenarbeit (GIZ) GmbH. Retrieved from https://www.giz.de/fachexpertise/downloads/giz-2016-eninnovations_and_emerging_trends-agricultural_insurance.pdf.

[8] IFC (2018, February 06). IFC increases reach of index insurance for small holder farmers in Zambia. IFC Press Release. Retrieved from

https://www.indexinsuranceforum.org/news/ifc-increasesreach-index-insurance-small-holder-farmers-zambia

[9] Iturrionz, R. (2009). Agricultural Insurance. Retrieved from $\mathrm{http}$ //siteresources. worldbank.org/FINANCIALSECTOR/Res ources/Primer12_Agricultural_Insurance.pdf.

[10] Joseph, W. G. (October 2015). Agricultural Insurance and the World Trade Organization. IFPRI Discussion Paper 01473. Washington, DC: International Food Policy Research Institute. Retrieved

fromhttp://ebrary.ifpri.org/cdm/singleitem/collection/p15738c oll2/id/129733/rec/1.

[11] Li, X. (2014). Retrieved from http://www.casact.org/education/reinsure/2014/14_Reinsuranc e_Onsite.pdf.

[12] Lomot, M. J., Lyskawa, K. and Rozumek, P. (2015, May). Farm income insurance as an alternative for traditional crop insurance. Elsevier B. V. Conference conducted at the meeting of the economies of Balkan and Eastern Europe countries in the changed world, EBEEC 2015, May 8-10. Retrieved from www.sciencedirect.com.

[13] Marza, B., Angelescu, C. and Tindeche, C. (2015). Agricultural insurance and food security. The new climate change challenges. In Elsevier B. V. Conference conducted at the meeting of the economic prospects in the context of growing global and regional interdependencies, IECS 2015. Retrieved from www.sciencedirect.com.

[14] Ministry of Agriculture. (2018). Agriculture at a Glance. Retrieved from http://www.moa.gov.bd/site/page/4fb627c0d806-4a7e-a1 cd-b67d4bc85159/Bangladesh-Agriculture-at-aGlance.

[15] Mridha, M. U. (August 16, 2016). Floods cut vegetable exports by half. The Daily Star. Retrieved from http://www.thedailystar.net/business/floods-cut-vegetableexports-half-1270402.

[16] Nagaraju, J. (2014). Agricultural Insurance Schemes in India. Osmania Journal of International Business Studies 09(1), 00973-5372 (P) 139-141. Retrieved from https://docs.google.com/file/d/0Bz5dEytrJdzUno3NDVBSHdFTWs/edit?pli=1.

[17] Porth, L. and Tan, K. S. (2015). Agricultural Insurance. The Actuary Magazine. Retrieved from https://www.soa.org/Library/Newsletters/The.../act-2015vol12-iss2-porth-tan.pdf.

[18] Quiggin, J., Karagiannis, G. and Stanton J. (n.d.). Crop insurance and crop production: an empirical study of moral hazard and adverse selection. Australian Journal of Agricultural economics 37(2), 95-113. Retrieved from http://www.uq.edu.au/economics/johnquiggin/JournalArticles 93/Cropins93.pdf.

[19] SadharanBima Corporation. (2017). Weather Index-Based Crop Insurance. Retrieved from http://www.sbc.gov.bd/site/page/2392c19a-5c74-49d5-ade5bca63989a911/Weather-Index-Based-Crop-Insurance.

[20] Swain, M. (2014). Crop Insurance for Adaptation to Climate Change in India. Asia Research Centre (ARC). Retrieved from http://www.lse.ac.uk/asiaResearchCentre/_files/ARCWP61Swain.pdf.

[21] USDA RMA (US Department of Agriculture, Risk Management Agency). (2018). Improvements to Crop Insurance continue in 2018. Retrieved from https://www.rma.usda.gov/news/2017/12/2017accomplishmen ts.pdf.

[22] WFP (World Food Program). (n, d). Weather Index-based Insurance in Agricultural Development: A Technical Guide. Publications. Retrieved from https://www.wfp.org/content/weather-index-based-insuranceagricultural-development-technical-guide.

[23] Wikipedia. (n, d). Agriculture in Bangladesh. Retrieved from https://en.wikipedia.org/wiki/Agriculture_in_Bangladesh.

[24] Wikipedia. (n, d). Crop Insurance. Retrieved fromhttps://en.wikipedia.org/wiki/Crop_insurance. 